\title{
Corrosion Studies on Concrete Using Treated and Untreated Textile Effluent and Impact of Corrosion Inhibitor
}

\author{
K Nirmalkumar \\ Department of Civil Engineering \\ Kongu Engineering College \\ Perundurai-638 052, Tamil Nadu, India \\ Tel: 98-43-266-570 E-mail: nirmal2555080@yahoo.co.in \\ V Sivakumar \\ Department of Chemical Engineering \\ Kongu Engineering College \\ Perundurai-638 052, Tamil Nadu, India
}

\begin{abstract}
An attempt was made to use the waste water from textile industry for construction purpose, so that the shortage in water can be greatly reduced and the waste water can be suitably disposed for safe guarding the environment. The basic properties of the treated and untreated water from the textile industry were tested and the results were found to be satisfactory such that it can be used for construction purposes. By using the waste water from the textile industry cubes, cylinders and beams were casted and tested for its mechanical properties (compressive strength, tensile strength, flexural strength etc) and the result was found to be satisfactory. Hence the experiment was continued on for durability studies where the corrosion attack was also studied. The results of other durability studies were found to be satisfactory. In this experimental study the results of specimen's casted using treated and untreated textile water were compared with the specimens casted with potable water. Since there was some corrosion, admixtures were added to counter act the same and the results were found to be satisfactory.
\end{abstract}

Keywords: Concrete, Calcium nitrate, Concare, Cempatch-R

\section{Introduction}

The term corrosion is defined as an act or process of gradual wearing away of a metal due to chemical or electrochemical reaction by its surroundings such that the metal is converted into an oxide, salt or some other compound. It indicates the deterioration and loss of material due to chemical attack.

In this study comparison was made between specimens (cylinder) casted using treated textile effluent, untreated textile effluent and potable water. There was deterioration due to corrosion attack and to counteract the corrosion attack concare and calcium nitrate was added on trial and error basis and it was found that $2.5 \%$ concare and $2.0 \%$ calcium nitrate was found to be suitable. In addition cempatch-R coating was done on the reinforcement bar and the effect was also studied. The experimental study was conducted for three grades of concrete i.e. $\mathrm{M}_{20}, \mathrm{M}_{25}$ and $\mathrm{M}_{30}$, but here only for $\mathrm{M}_{20}$ grade of concrete the corrosion studies were analyzed and discussed in detail. The results of other two grades $\mathrm{M}_{25}$ and $\mathrm{M}_{30}$ were also same as $\mathrm{M}_{20}$ grade of concrete. The specimens were tested after 28 days, 180 days, 1 year, 2 year and 2.5 years of curing.

\section{Experimental}

The natural river sand was used, tested and conforming to the specifications IS 2386 (Part II)-1963, IS 2386 (Part III)-1963, IS 2386 (Part IV)-1963 and IS 2386 (Part VI)-1963. The fines modulus of sand used is 2.80 with a specific gravity of 2.54. A good quality crushed granite coarse aggregates was used and the coarse aggregate was tested as per the specifications IS 2386 (Part III)-1963, IS 2386 (Part IV)-1963, IS 2386 (Part V)-1963, IS 2386 (Part VII)-1963 and IS 2386 (Part VIII)-1963. The crushing value of coarse aggregate is tested as per IS 9376-1979, and its impact value is tested as per IS 9377-1979. The cement used was 53 grade PP cement. In addition few other properties were tested as per the procedure given by M S Shetty (2001) and Rangwala (1997). Concrete mixes were designed for $\mathrm{M}_{20}, \mathrm{M}_{25}$ and $\mathrm{M}_{30}$ to study the mechanical strength properties and durability properties as per IS 10262-1982. Standard cylindrical steel moulds measuring $150 \mathrm{~mm}$ diameter and $300 \mathrm{~mm}$ height were used for the preparation of test specimen for splitting 
tensile strength test and corrosion attack test as per IS 10086-1982. The admixture was selected and used based on the guidelines of the specifications IS 9103-1978 and ACI 212.

A reinforcement steel bar of $20 \mathrm{~mm}$ diameter and $300 \mathrm{~mm}$ long was weighed and noted down. A cylinder of $150 \mathrm{~mm}$ diameter and $300 \mathrm{~mm}$ height was used for preparing the specimen. The steel bar, explained earlier was held in position and concreting was done with $300 \mathrm{~mm}$ cover. Care should be taken so that the rod stayed in position while compacting. The specimen is allowed to cure for 28 days. The test setup that essentially measures resistivity of concrete consists of a constant DC supply providing constant voltage of 120 Volts through a shunt in a constant voltage mode and 80 million Ampere in constant current mode. The test was carried out in a $6 \% \mathrm{NaCl}$ solution with an embedded reinforcement bar as a working electrode a shown in Fig.1 and a copper bar as a counter electrode. The variable parameter voltage was recorded at every 15 minutes interval for 6 hours in constant current study. The set up was kept for 5 days without disrupting the power supply. The solution turns to reddish brown in color due to the formation of rust. Then the specimens are removed from the set up, dried in air, visually inspected and carefully split open to access the corroded steel bar. The reinforcement bar was then cleaned as per ASTM G1 of 1981 by dipping it in Clark's solution ( $\mathrm{HCl}$ of specific gravity 1019 litre + antimony trioxide $20 \mathrm{gm}+$ stannous chloride $50 \mathrm{gm}$ ) for 25 minutes. Each bar was weighed again to the accuracy of $0.1 \mathrm{mg}$ to find out the change in weight. Figure 2 shows the view of test setup.

\section{Result and Discussion}

There is a continuous loss of weight of reinforcement bar embedded in the concrete with respect to age of concrete from 28 days of casting of concrete to 2.5 year of casting of concrete. Initially after 28 days of curing, the loss of weight reinforcement bar is approximately $5 \%$ for potable water, $5.5 \%$ for treated textile water and $6.0 \%$ for untreated textile water. The loss of weight of reinforcement bar gradually increases along with the time and at the end of 2.5 year the loss of weight reinforcement bar is approximately $6.25 \%$ for potable water, $6.5 \%$ for treated textile water and $7.0 \%$ for untreated textile water.

When $2.5 \%$ of concare admixture is added, the loss of weight of reinforcement is slightly reduced. Initially at the beginning (after 28 days), the loss of weight of reinforcement bar is less than $1.25 \%$ and at the end of 2.5 year the loss of weight of reinforcement bar is less than $2.25 \%$ for all the specimens cast using potable water, untreated textile Water and treated textile water. When $2.0 \%$ of calcium nitrate is added the loss of weight reinforcement bar is same as that of adding $2.5 \%$ concare admixture.

In order to reduce the corrosion further, the reinforcement is coated with cempatch-R. There is a great loss in weight of reinforcement i.e even at the end of 2.5 year; the loss in weight of reinforcement is less than $0.25 \%$ for all types of water. In addition when $2.5 \%$ concare and $2.0 \%$ calcium nitrate is added along with cempatch- $\mathrm{R}$ coating, the loss in weight is less than $0.03 \%$ at the end of 2.5 year for all types of water which is almost very negligible. All the comparisons are given in figure's 3 to 8 .

\section{Conclusion}

From the discussion it is clear that the treated and untreated textile water can be used for construction purpose after adding concare and calcium nitrate admixture. It will be a boon for the environment if the industrial water is used for construction purpose. The problem of disposal of the waste water will be greatly reduced.

\section{References}

ACI Committee 212 (2002), Classification of Admixtures, ACI manual of concrete practice, American Concrete Institute, Farmington Hills, USA.

IS 2386 (Part II)-1963 (1963), Indian Standard Methods of test for aggregates for concrete: deterious materials and organic impurities, VIII reprint April 1996, Bureau of Indian Standard, New Delhi-110 002.

IS 2386 (Part III)-1963 (1963), Indian Standard Methods of test for aggregates for concrete: Specific gravity, density, voids, absorption \& bulking, VIII reprint March 1997, Bureau of Indian Standard, New Delhi-110 002.

IS 2386 (Part IV)-1963 (1963), Indian Standard Methods of test for aggregates for concrete: Mechanical properties, IX reprint June 1996, Bureau of Indian Standard, New Delhi-110 002.

IS 2386 (Part V)-1963 (1963), Indian Standard Methods of test for aggregates for concrete: Soundness, VIII reprint November 1996, Bureau of Indian Standard, New Delhi-110 002.

IS 2386 (Part VI)-1963 (1963), Indian Standard Methods of test for aggregates for concrete: Mortar making properties of fine aggregates, VIII reprint April 1997, Bureau of Indian Standard, New Delhi-110 002.

IS 2386 (Part VII)-1963 (1963), Indian Standard Methods of test for aggregates for concrete: alkali aggregate reactivity, IX reprint June 1996, Bureau of Indian Standard, New Delhi-110 002.

IS 2386 (Part VIII)-1963 (1963), Indian Standard Methods of test for aggregates for concrete: Petrographic examination, VII reprint August 1991, Bureau of Indian Standard, New Delhi-110 002. 
IS 9376-1979 (1979), Indian Standard Specification for Apparatus for measuring aggregate crushing value and 10\% fine value. I reprint May 1997. Bureau of Indian Standard, New Delhi-110 002.

IS 9377-1979 (1979), Indian Standard Specification for apparatus for aggregate impact value. I reprint July 1990. Bureau of Indian Standard, New Delhi-110 002.

IS 10262-1982 (1982), Indian Standard Recommended guide lines for concrete mix design V print march 1998. Bureau of Indian Standard, New Delhi-110 002.

IS 10086-1982 (1982), Indian Standard specification for moulds for use in tests of cement and concrete-V Reprint December 1995, Bureau of Indian Standard, New Delhi-110 002.

IS 9103-1978 (1978), Indian Standard Specification for addition of admixtures, Indian Standards Institution, New Delhi-110 002.

Rangwala. (1997), Engineering Materials, Charotar publishers., pp 150-158.

Shetty, M. S. (2003), Concrete Technology Theory and Practice - S.Chand \& Company Ltd, pp 399-400,429-438, 449-501.

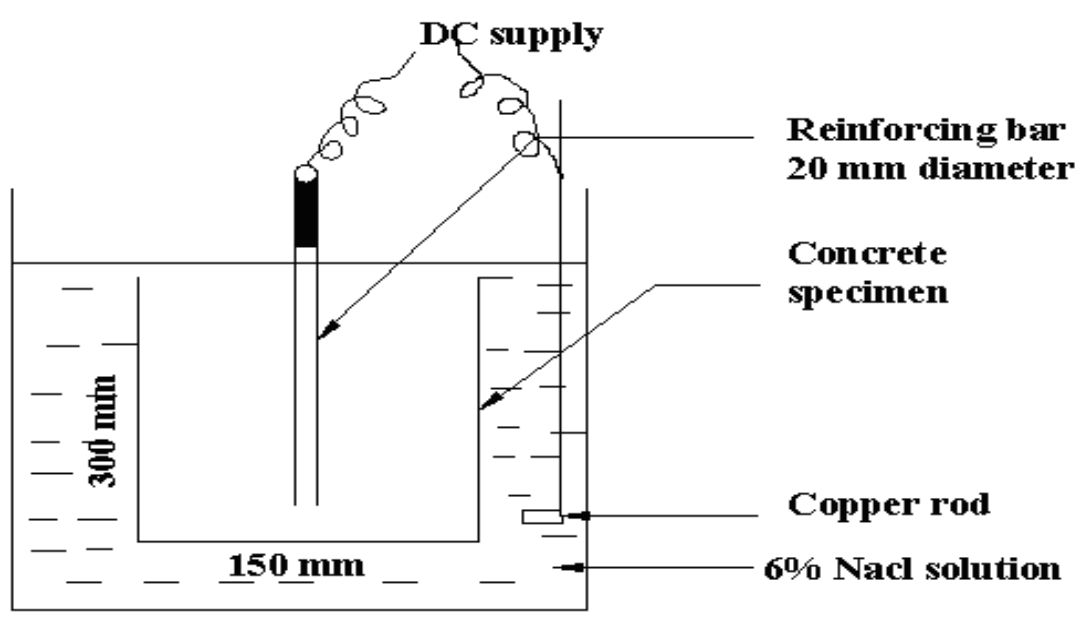

Figure 1. Accelerated Corrosion Test Setup 


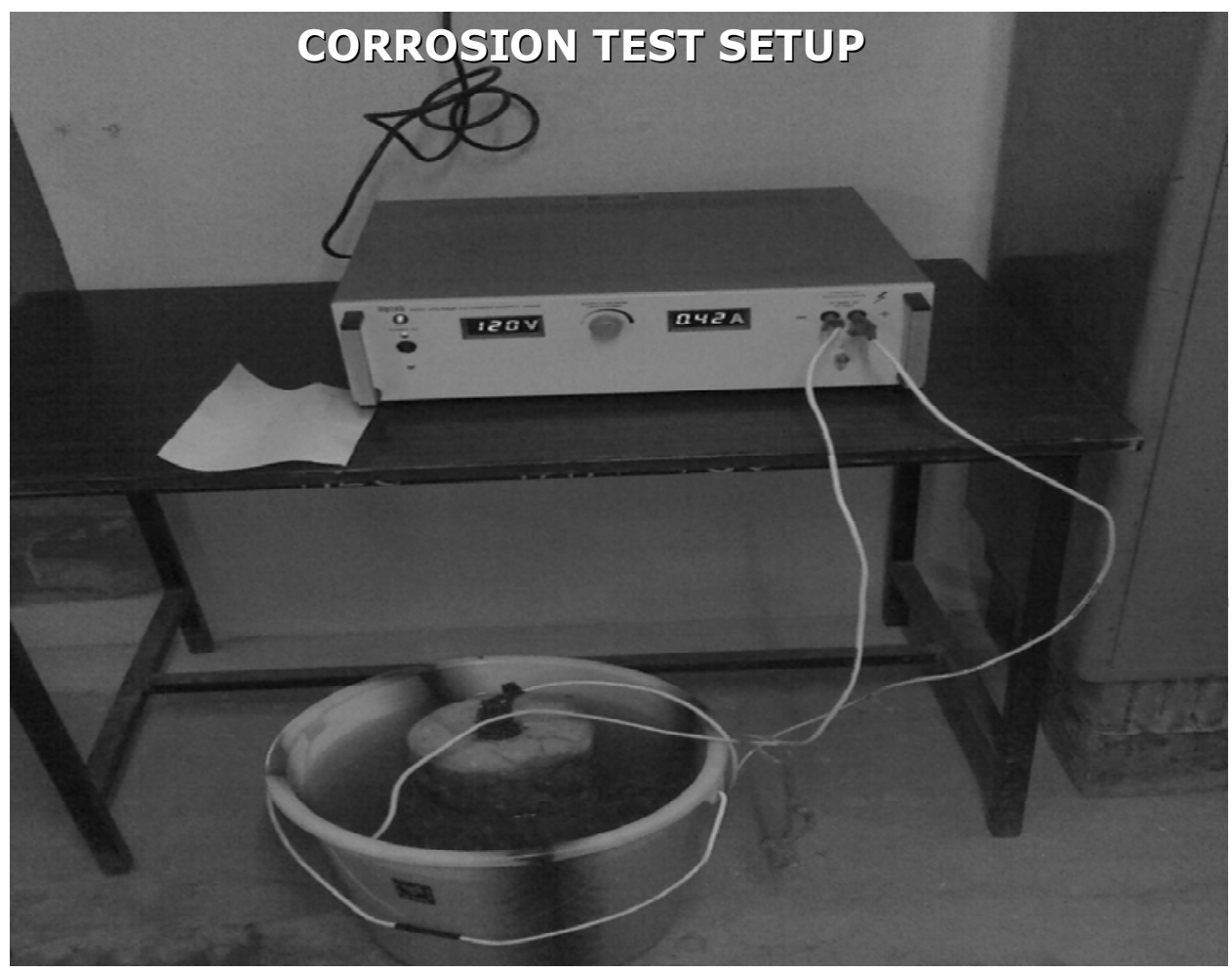

Figure 2. Corrosion Test Setup

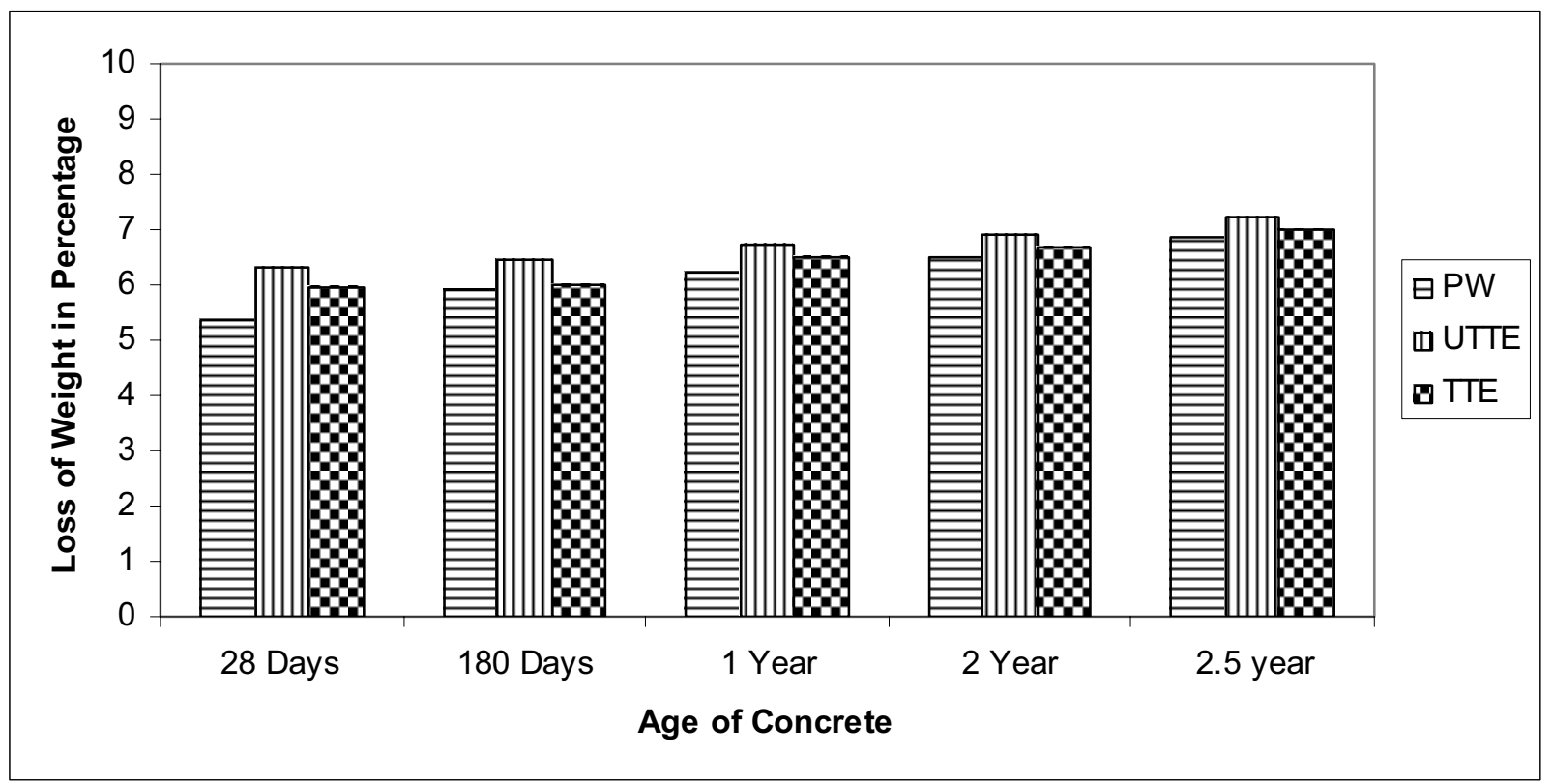

Figure 3. Comparison of loss of weight of reinforcement bar due to corrosion for potable water, untreated textile Water and treated textile water for $\mathrm{M}_{20}$ grade of concrete without adding admixture 


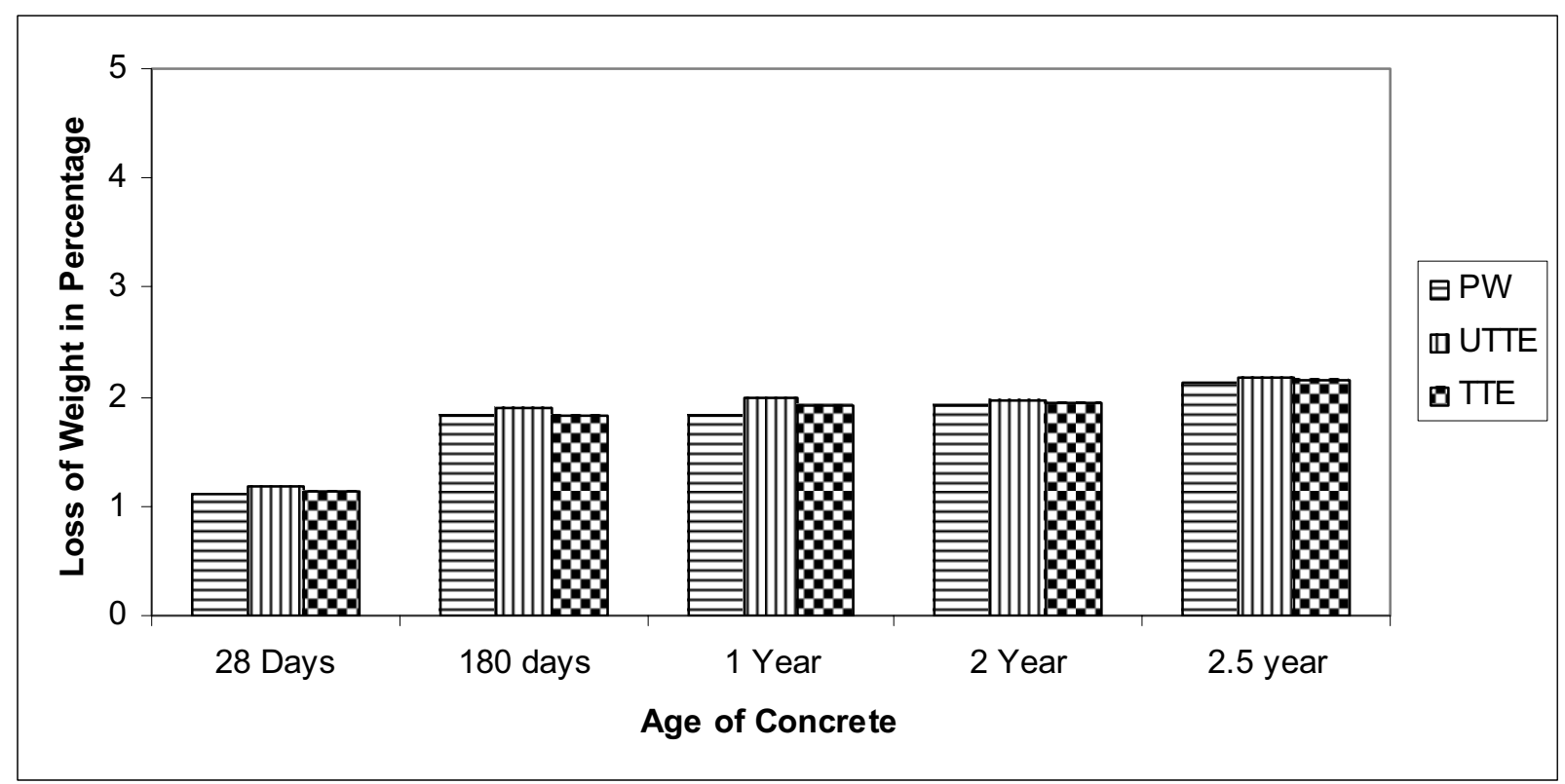

Figure 4. Comparison of loss of weight of reinforcement bar due to corrosion for potable water, untreated textile Water and treated textile water for $\mathrm{M}_{20}$ grade of concrete adding $2.5 \%$ concare

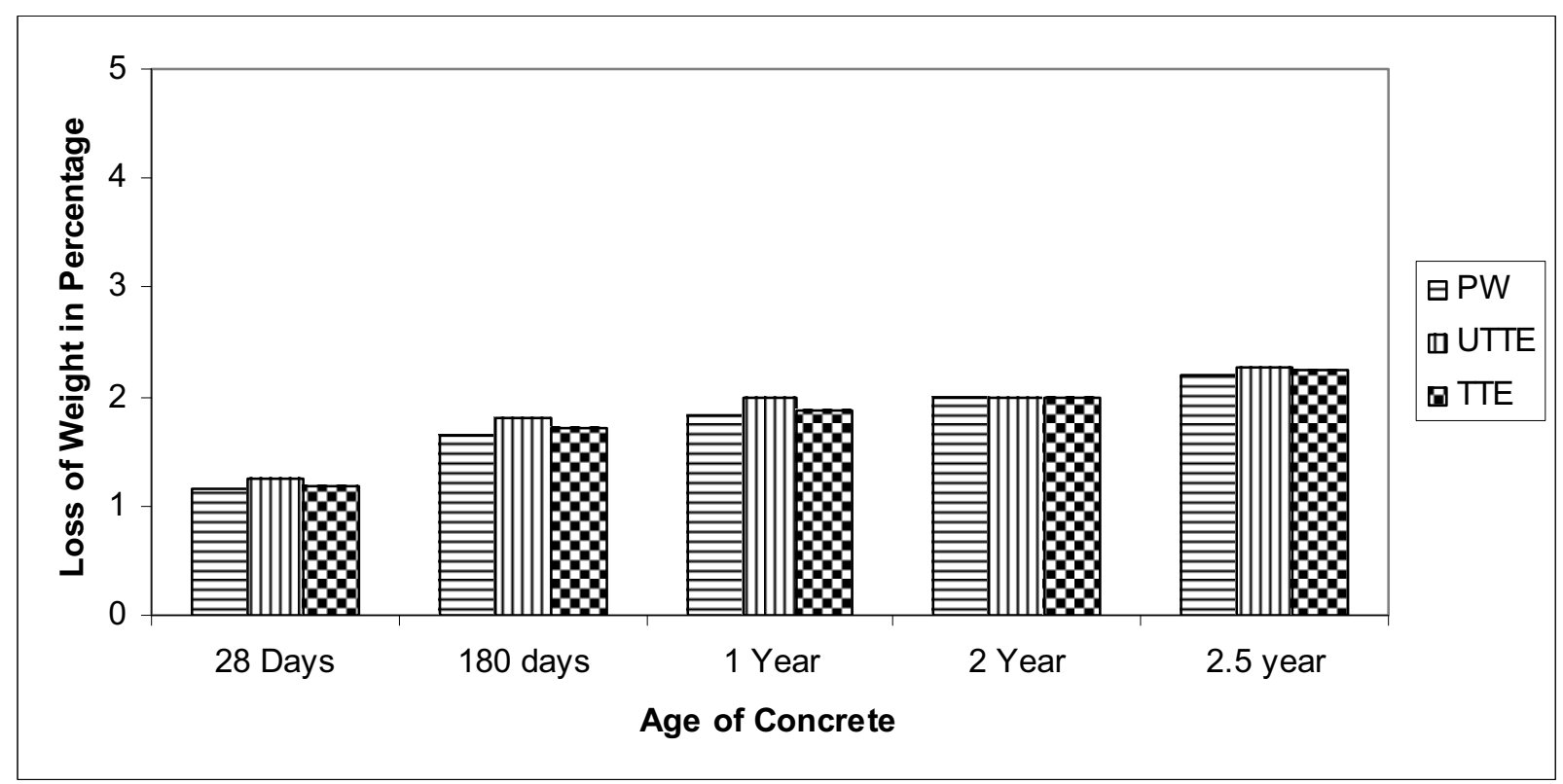

Figure 5. Comparison of loss of weight of reinforcement bar due to corrosion for potable water, untreated textile Water and treated textile water for $\mathrm{M}_{20}$ grade of concrete adding $2.0 \%$ calcium nitrate 


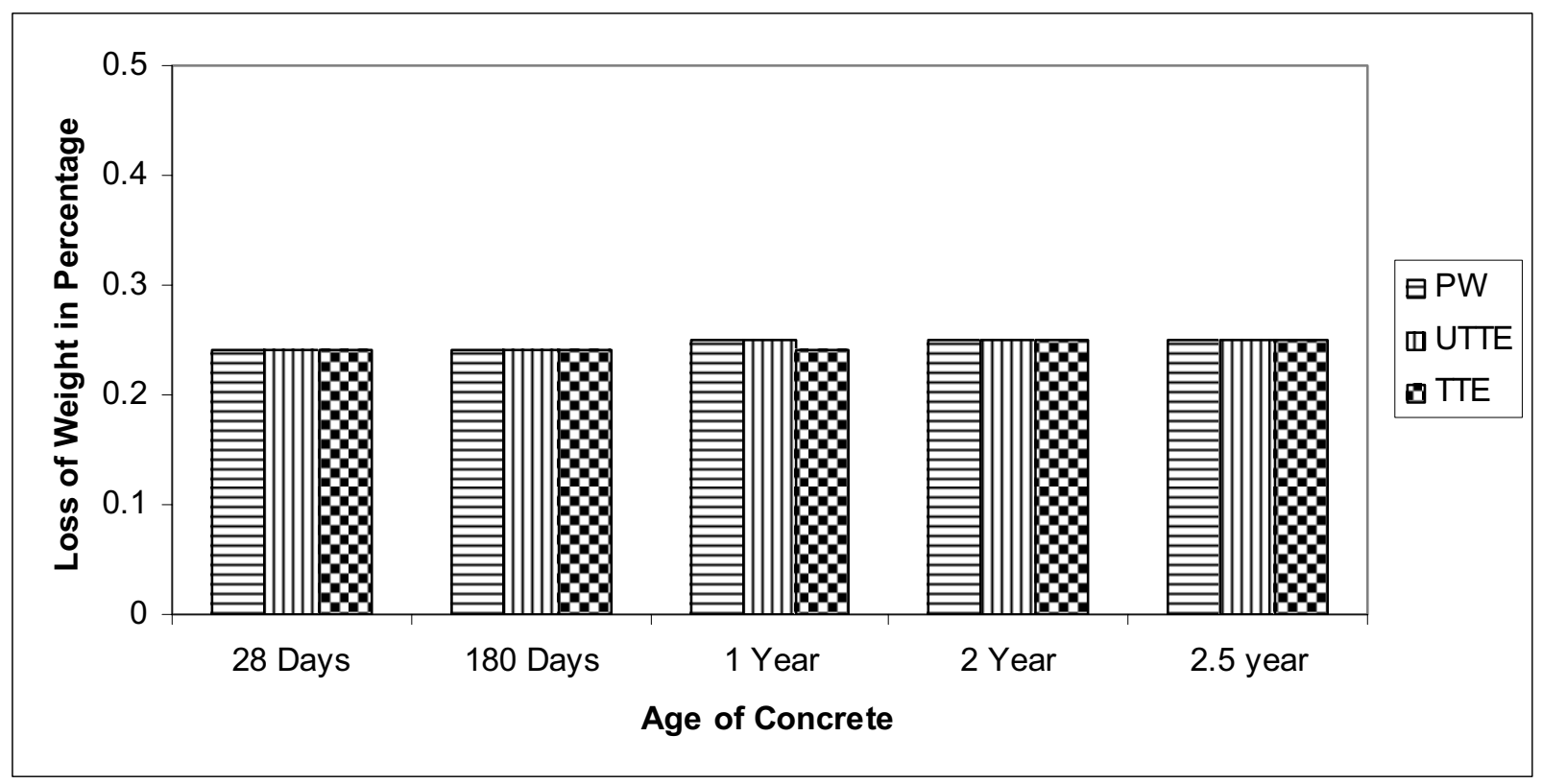

Figure 6. Comparison of loss of weight of cempatch-R painted reinforcement bar due to corrosion for potable water, untreated textile Water and treated textile water for $\mathrm{M}_{20}$ grade of concrete without adding admixture

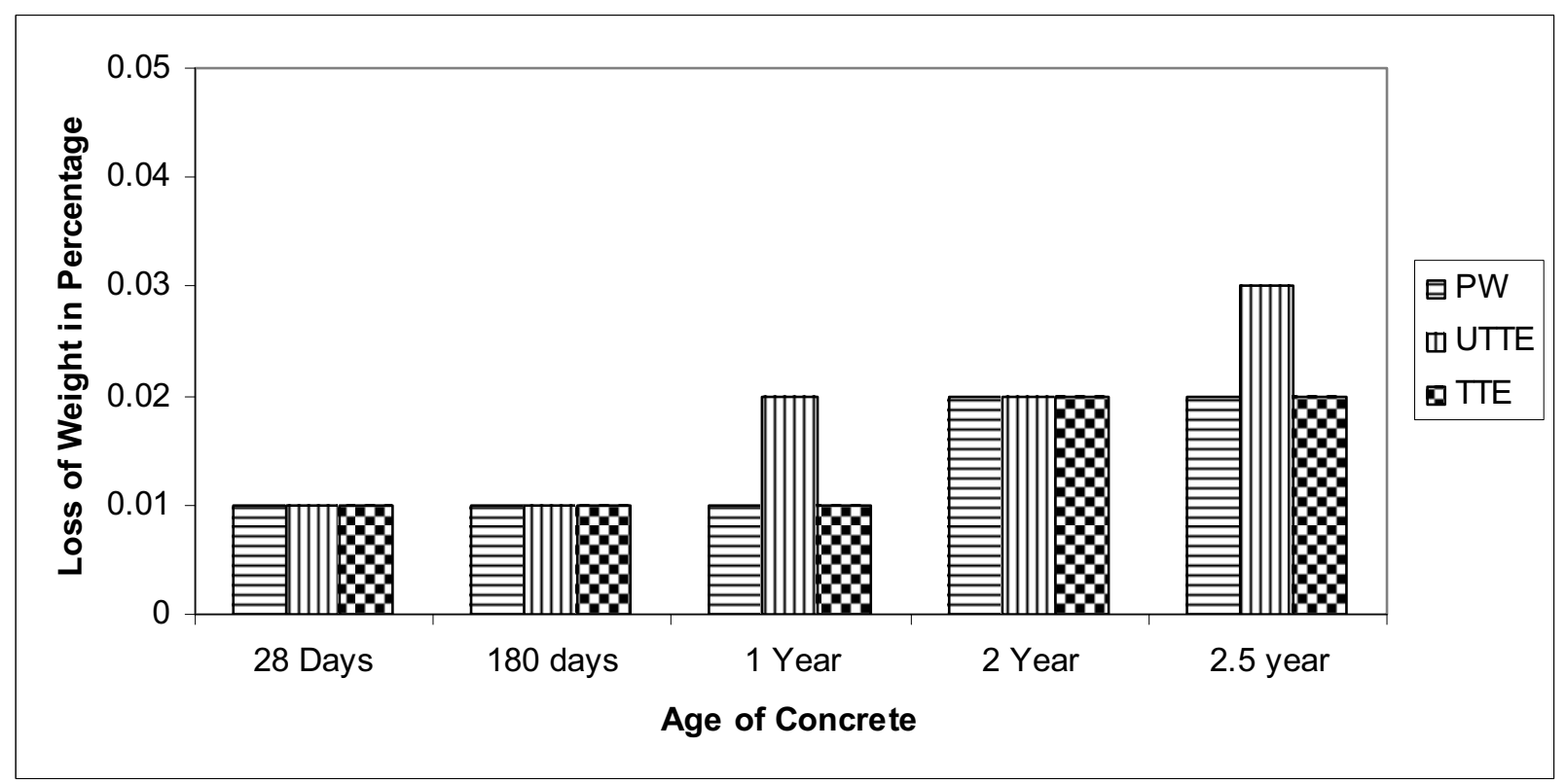

Figure 7. Comparison of loss of weight of cempatch-R painted reinforcement bar due to corrosion for potable water, untreated textile Water and treated textile water for $\mathrm{M}_{20}$ grade of concrete adding $2.5 \%$ concare 


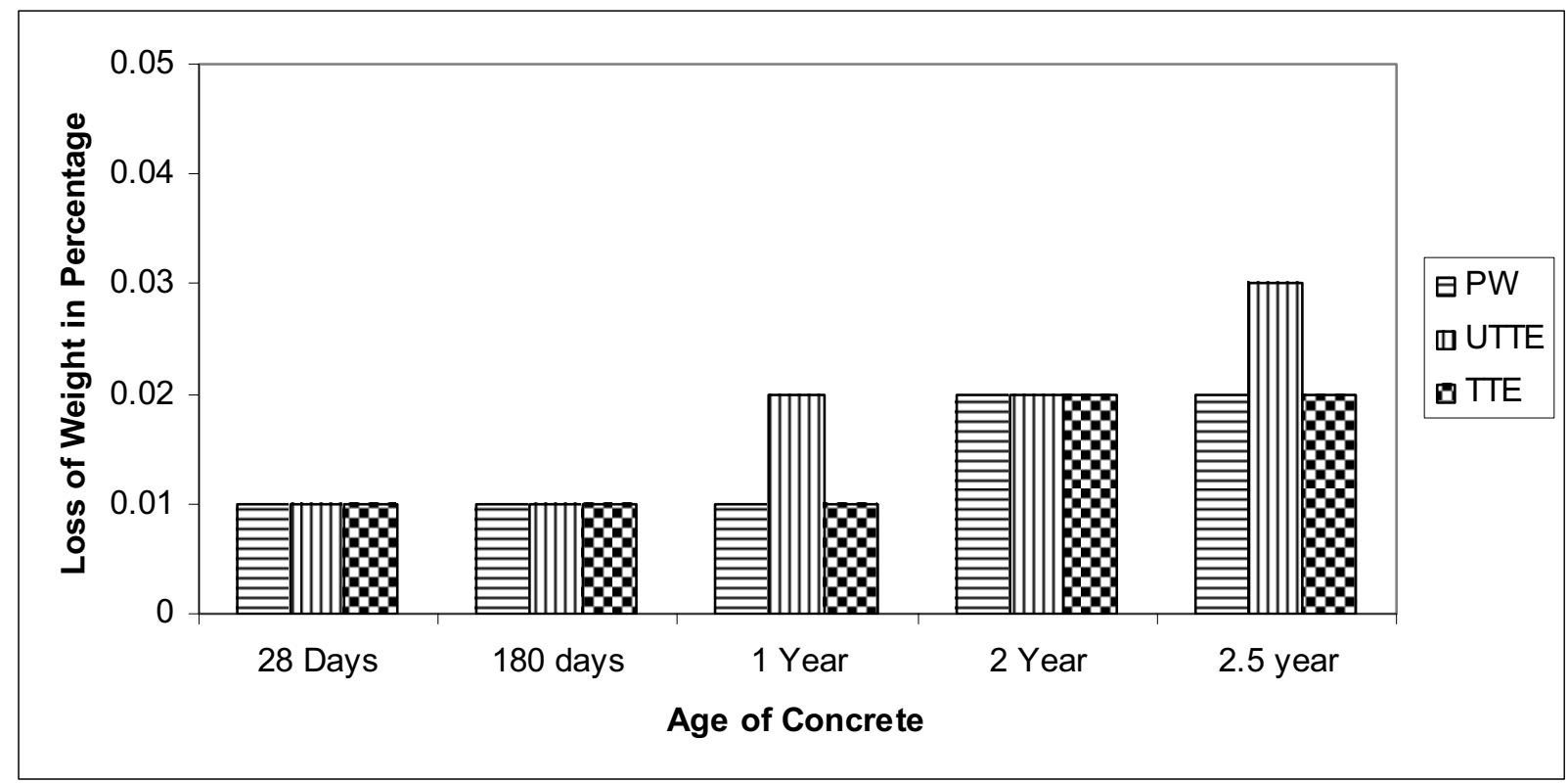

Figure 8. Comparison of loss of weight of cempatch-R painted reinforcement bar due to corrosion for potable water, untreated textile Water and treated textile water for $\mathrm{M}_{20}$ grade of concrete adding $2.0 \%$ calcium nitrate 